\title{
"Unlearning" construction types transferred from the L1: Evidence from adult L1 Afrikaans L2 French
}

\author{
Simone Conradie \\ Department of General Linguistics, Stellenbosch University, 7600 Stellenbosch, South Africa \\ E-mail: sconra@sun.ac.za
}

\begin{abstract}
Two construction types that are allowed in Afrikaans but not in French are transitive expletive constructions and full-NP object shift constructions. The study reported here tested whether Afrikaansspeaking advanced adult learners had knowledge of the ungrammaticality of these two construction types in the target L2 French, given that they had not been instructed about this ungrammaticality. The results of this study show that a large number of the L2 learners had indeed acquired knowledge of this ungrammaticality, despite the absence of (explicit) negative evidence to this effect, raising the question of which types of input or evidence learners make use of in L2 acquisition.
\end{abstract}

Keywords: adult L2 acquisition, Afrikaans, French, different types of input, unlearning construction types

\section{Introduction}

It is an indisputable fact that in order to be able to acquire a particular second language (L2), learners need input in that L2. A number of researchers who assume that Universal Grammar (UG) is operative in adult L2 acquisition, have investigated the role that different types of input play in the L2 acquisition process - see, for example, White 1991, 1992; Schwartz and Gubala-Ryzak 1992; Schwartz 1993; Trahey and White 1993; Carroll 1999; and Unsworth 2008. One way of categorising the different types of L2 input is by means of the distinction between primary linguistic data (PLD) (what I will refer to as "positive evidence") and negative evidence. Positive evidence provides the learner with evidence as to what is grammatical in the language, and consists of the L2 utterances that the learner is exposed to. Negative evidence, on the other hand, provides the learner with evidence as to what is ungrammatical in the L2, and consists of explicit teaching and corrective feedback (Schwartz 1993:147-148). If a learner of English hears the utterance Yesterday I went to school, this provides him/her with positive evidence, evidence for a number of properties of English. If a learner of English is told that one cannot say Yesterday went I to school, this constitutes negative evidence, information about something which is ungrammatical in the language.

The, again relatively uncontroversial, claim is that first language (L1) learners manage to acquire their native language completely on the basis of positive evidence alone: they do not require negative evidence; they are usually not exposed to it; and even if they are, they seem 
not to use it (Marcus 1993; Schwartz 1993:151). For L2 learners, the situation is different. Classroom L2 learners are definitely exposed to negative evidence. The next question is whether L2 learners can and do use negative evidence, unlike L1 learners. And there is, of course, a whole body of literature on what the effect of instruction and negative evidence is on the L2 acquisition process - see, for example, Lightbown and Spada 1990; Long 1991; White, Spada, Lightbown and Ranta 1991; Carroll, Roberge and Swain 1992; Carroll and Swain 1993; Lyster and Ranta 1997; Lyster 1998; Ellis, Loewen and Erlam 2006; and Lyster and Mori 2006. Schwartz (1993), for example, claims that even though many L2 learners are exposed to negative evidence, UG can only make use of positive evidence. This does not mean that negative evidence cannot be used to learn something about the L2. The difference is that positive evidence leads to unconscious knowledge that is stored as part of the interlanguage (IL) grammar and that we use automatically, while negative evidence leads to conscious knowledge that is stored separately and that we can only access with a conscious effort. Schwartz (1993:149-153) refers to the latter type of knowledge as "learned linguistic knowledge", which underlies learned linguistic behaviour, as opposed to the learner's competence in the L2 (his IL grammar), which underlies his performance in the language. As Schwartz (1993:150) acknowledges, this distinction echoes Krashen's (1981) distinction between learned knowledge and acquired knowledge.

Another question is why L2 learners, unlike L1 learners, seem to require negative evidence to acquire certain properties of the target language. According to Schwartz (1993:148, 152), the reason for this is that L2 learners start out with the parameter settings of another language (their L1 - see the Full Transfer hypothesis of Schwartz and Sprouse 1996; White 1989, 2003), unlike L1 learners, who start out with a kind of "clean slate" or default parameter settings, and for this reason only L2 learners get themselves into tricky situations, where they require negative evidence to "unlearn" something that they have transferred from their L1.

In my understanding, the different settings of a "typical" parameter stand in opposition to each other (as in Figure 1). For example, with respect to the so-called verb-second (V2-)parameter (Travis 1991) a language is either V2 or non-V2. The setting of this parameter is indicated by the position of the verb in non-subject-initial main clauses (i.e. main clauses in which an element other than the subject - an adverbial phrase or a topicalised object - occurs in sentence-initial position): in non-subject-initial main clauses the verb appears in second position in V2-languages (such as German) and in third position in non-V2 languages (such as English). Consequently, the German-speaking learner of English need only notice that Yesterday I went to school (V3) is grammatical in English, to know that Yesterday went I to school (V2) is ungrammatical in English (since every language has either V2-constructions such as that in (1a) or V3-constructions such as that in (2a), but not both, in declarative clauses). In this way the learner can "unlearn" the V2-construction type (that he has transferred from his L1 German) on the basis of positive evidence (by "noticing" V3constructions in the L2 input); he does not need negative evidence to acquire this knowledge. 

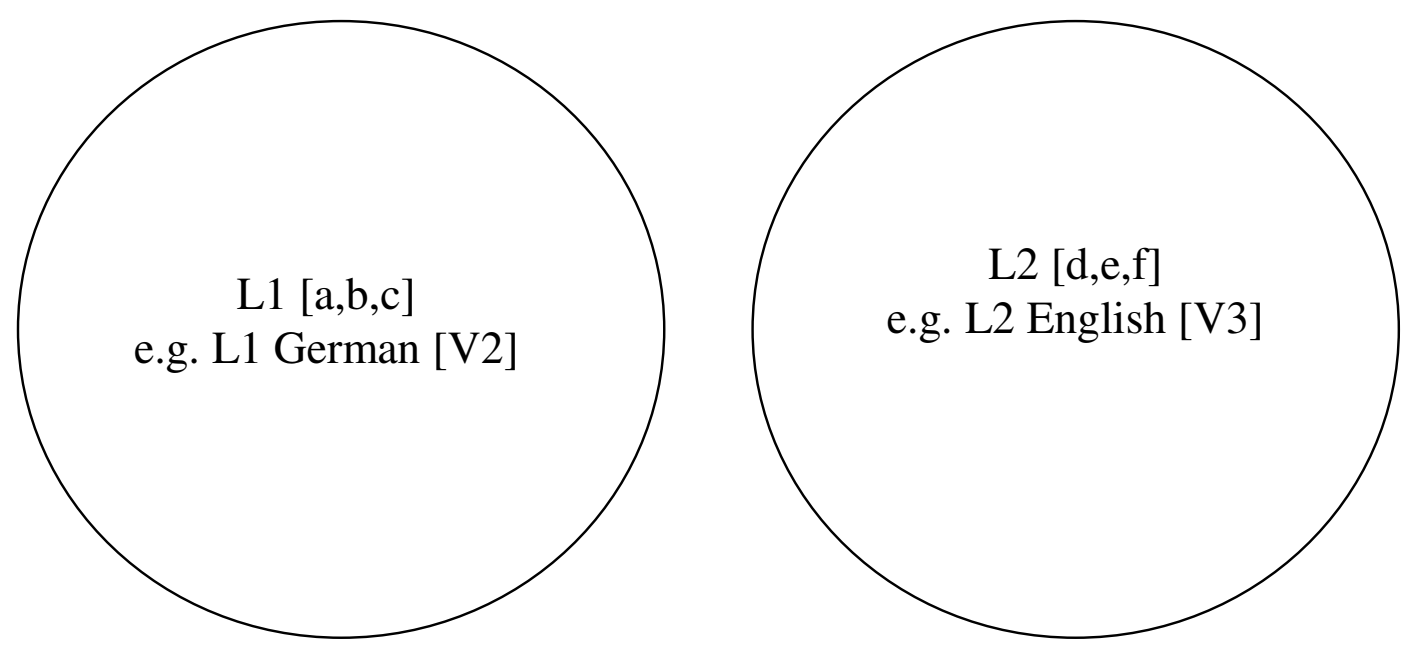

Figure 1. No subset-superset relation between L1 and L2

\section{(1) German}

a. Gestern ging ich zur Schule.

yesterday went I to school

"Yesterday I went to school."

b. *Gestern ich ging zur Schule.

yesterday I went to school

\section{(2) English}

a. Yesterday I went to school.

b. *Yesterday went I to school.

However, some parameter settings involve a subset-superset relationship (as in Figures 2 and 3 ), where the construction types allowed by one parameter setting constitute a subset of the construction types allowed by the other parameter setting.

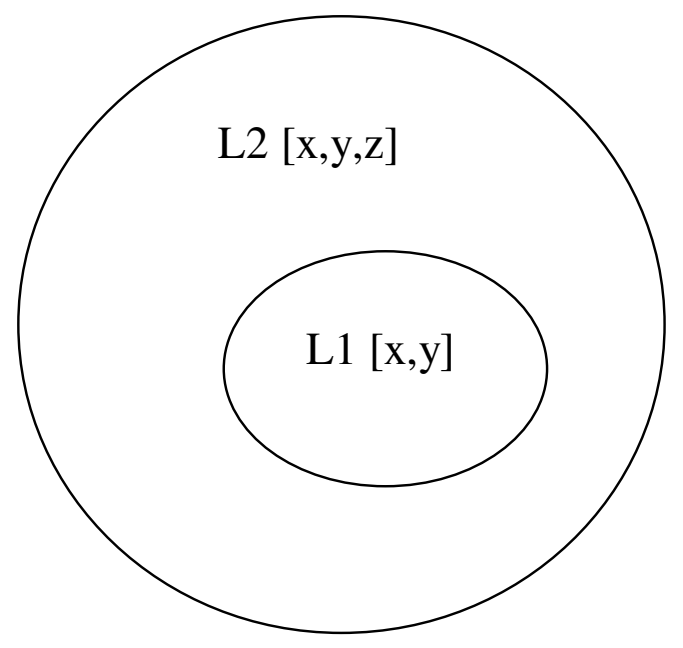

Figure 2. L1 subset - L2 superset 


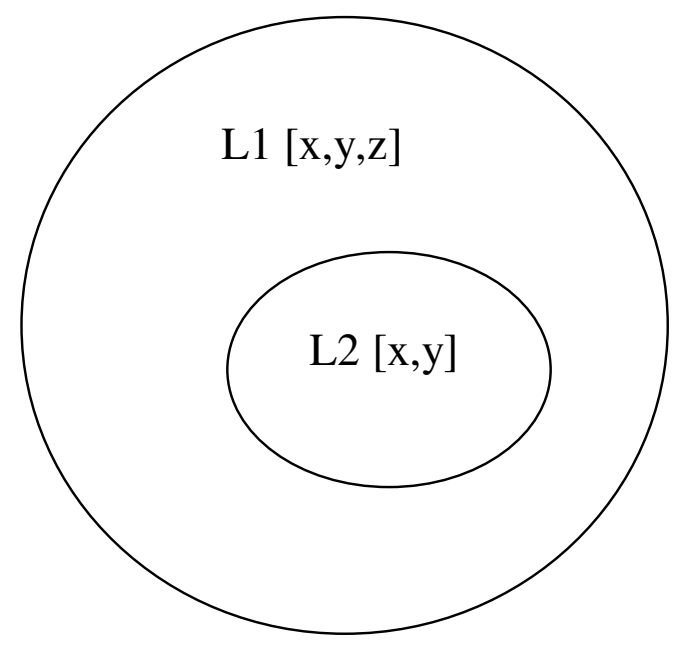

Figure 3. L1 superset - L2 subset

Parameter resetting should be unproblematic in the situation depicted in Figure 2. Following the Full Transfer hypothesis, the L2 learner will start out assuming that the target L2, like his $\mathrm{L} 1$, allows construction types $\mathrm{x}$ and $\mathrm{y}$ but he will have no problem acquiring construction type $\mathrm{z}$ since it will occur in the L2 input. The learner will thus acquire knowledge of this property of the target L2 on the basis of positive evidence. Parameter resetting might, however, be problematic in the situation depicted in Figure 3: the L2 learner starts out assuming that the target L2, just like his L1, allows construction types $\mathrm{x}, \mathrm{y}$ and $\mathrm{z}$ and the question is then how he could "unlearn" property $\mathrm{z}$, i.e. how he could come to know that $\mathrm{z}$ is in fact not allowed in the target L2. There is nothing in the L2 input that will show him that $\mathrm{z}$ is not allowed (no positive evidence), so in this case the learner needs negative evidence to acquire knowledge of the ungrammaticality of $\mathrm{z}$ (see White 1987 and MacLaughlin 1992 regarding the so-called Subset Principle). In Section 2 I will argue that exactly such a situation arises for Afrikaansspeaking learners of French. In Section 3 I will report on an investigation into the L2 acquisition of the relevant properties of French by Afrikaans-speaking learners. Section 4 offers a discussion of the results of the study, as well as a brief conclusion.

\section{An L1 superset - L2 subset situation in the L2 acquisition of French by Afrikaans-speaking learners}

Two construction types that are allowed in Afrikaans but not in French are transitive expletive constructions (or "TECs") and full-NP object shift constructions (or "OSCs").

(3) Afrikaans

a. Drie vrouens het koek verkoop by die fees. Vnon-TEC three women have cake sold at the festival "Three women sold cake at the festival."

b. Daar het drie vrouens koek verkoop by die fees.

$\sqrt{ }$ TEC there have three women cake sold at the festival "Three women sold cake at the festival." 
c. Die tuinier het dikwels [die gras] gesny. the gardener has often the grass cut "The gardener often cut the grass."

d. Die tuinier het [die gras] dikwels gesny. the gardener has the grass often cut "The gardener often cut the grass."

\section{(4) French}

a. Trois femmes ont vendu du gâteau à la fête. three women have sold cake at the festival "Three women sold cake at the festival."

b. *Il y avait trois femmes vendu du gâteau à la fête. EXPLETIVE three women have sold cake at the festival

c. Le jardinier a souvent coupé [l'herbe]. the gardener has often cut the grass "The gardener often cut the grass."

d. *Le jardinier a [l'herbe] souvent coupé. the gardener has the grass often cut $\sqrt{ }$ non-OSC

$\sqrt{ }$ OSC

$\sqrt{ }$ non-TEC

*TEC

$\sqrt{ }$ non-OSC

*OSC

TECs are constructions that contain both an expletive and a transitive verb. As is illustrated by the examples in (3b) and (4b), Afrikaans allows the transitive verb verkoop 'buy' to occur together with the expletive daar 'there', whereas French does not allow the transitive verb vendu 'buy' to occur together with the expletive il y (avait) (literally 'it there (has)').

OSCs are constructions in which the direct object NP has been moved leftwards across an element that is taken to mark the left edge of VP (a sentence medial adverb, floating quantifier or negative element - for the sake of convenience these elements are referred to as "left-edge markers"). As is illustrated by the examples in (3d) and (4d), Afrikaans allows the direct object die gras 'the grass' to precede the sentence-medial adverb dikwels 'often', whereas French does not allow the direct object NP l'herbe 'the grass' to precede the sentence-medial adverb souvent 'often'.

Bobaljik and Thráinsson (1998) propose that these two superficially unrelated construction types - TECs and OSCs - are linked to each other under the Split-IP parameter (SIP) (cf. also Thráinsson 1996). On their view languages differ as to how many projections make up their IP-complex: [-SIP] languages have a simple, unsplit IP, whereas [+SIP] languages have an IP that is split up into AgrSP, TP and AgrOP. Of course, there have been substantial developments within minimalist syntax since 1998. On this matter, the reader is referred to Conradie (2007:54-60) for a discussion of the SIP and the relevant developments within minimalist syntax, as well as an argument that none of these developments affects the validity of Bobaljik and Thráinsson's SIP.

Because TECs and OSCs require additional specifier positions within the IP-complex, these construction types are only allowed in [+SIP] languages; [-SIP] languages simply do not have the phrase structure to accommodate these construction types. If every language allowed (i) either TECs or non-TECs and (ii) either OSCs or non-OSCs (in the same way that every language allows either V2-constructions or V3-constructions), the relationship between languages such as Afrikaans and French would be one of mutual exclusivity with respect to these construction types (cf. Figure 1). However, the data in (3) and (4) illustrate that a subset- 
superset relation exists between these two languages in that French allows a subset of the construction types allowed by Afrikaans: Afrikaans allows TECs, non-TECs, OSCs and nonOSCs, whereas French allows only non-TECs and non-OSCs.

In the L2 acquisition of Afrikaans by L1 speakers of French, we would find the configuration in Figure 4 (cf. Figure 2). French-speaking learners of Afrikaans would transfer from their L1 French the assumption that Afrikaans allows only non-TECs and non-OSCs but they would soon discover, on the basis of positive evidence, that Afrikaans also allows TECs and OSCs as well, since there would be ample evidence for this in the L2 Afrikaans input.

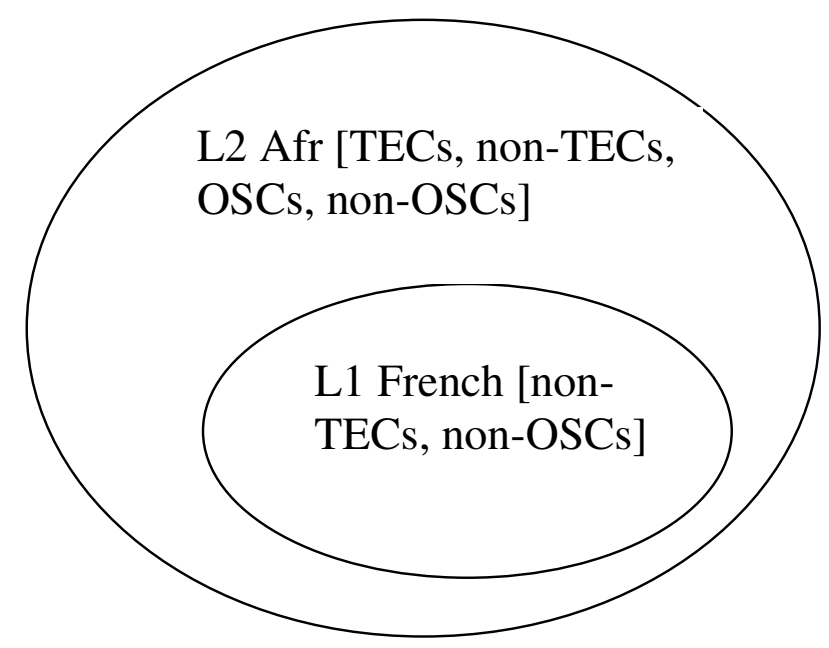

Figure 4. L1 French subset - L2 Afrikaans superset

In the L2 acquisition of French by L1 speakers of Afrikaans, on the other hand, we would find the more problematic configuration depicted in Figure 5 (cf. Figure 3). Afrikaans-speaking learners of French would transfer from their L1 Afrikaans the assumption that French allows TECs, non-TECs, OSCs and non-OSCs and there would be nothing in the L2 French input, i.e. no positive evidence, to indicate to them that French does not allow TECs and OSCs. Therefore, acquiring knowledge of the ungrammaticality of these two construction types seems to require negative evidence. The problem is that the required negative evidence is not available since students in L2 French classrooms are not instructed on the impossibility of these construction types. Assuming that negative evidence is required but is not available, the prediction is that even advanced Afrikaans-speaking learners of French should still be producing TECs and OSCs and/or judging these construction types as grammatical. Section 3 reports on a study that set out to test this prediction. 


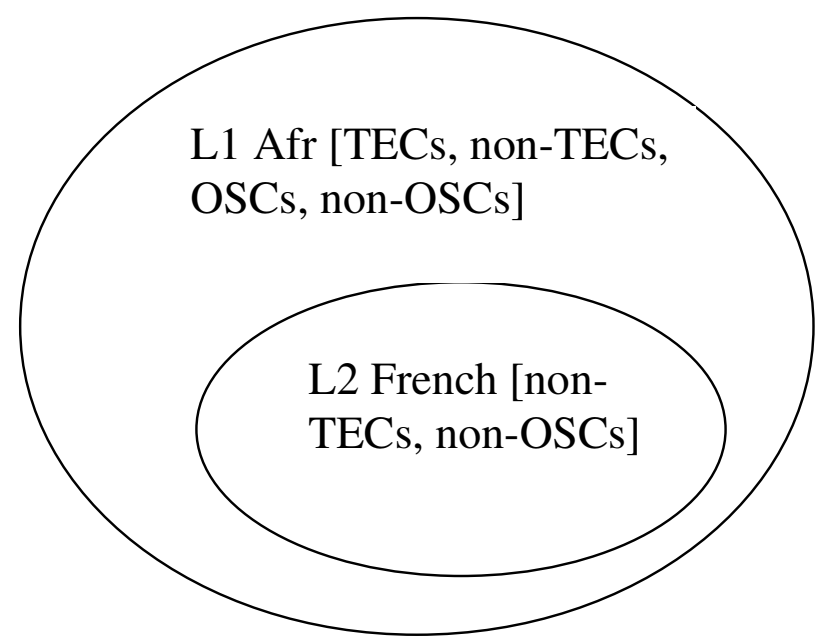

Figure 5. L1 Afrikaans superset - L2 French subset

\section{Evidence for the "unlearning" of TECs and OSCs by Afrikaans-speaking learners of French}

\subsection{Participants}

As part of a larger study (Conradie 2005), I set out to test the prediction that Afrikaansspeaking learners of French would be unable to acquire knowledge of the ungrammaticality of TECs and OSCs in the absence of negative evidence. 21 Afrikaans-speaking advanced learners of French participated in the study, as well as 21 native speakers of French, who acted as a control group. Most of the French Controls were born in Western Africa - Gabon $(n=16)$, Cameroon $(n=1)$ and the Ivory Coast $(n=1)-$ and had spoken either only French or French plus another language (Fang, Yipunu, Getsogo, Ntumu or Bamoun) at home while growing up. (Even those participants who had spoken an additional language at home, said that they felt most comfortable in French, that this was the language they had received their education in and that they were now using in their homes and at work.) The remaining three French Controls were born in France and had spoken only French at home while growing up. The French Controls were aged between 19 and 36 (most were in their twenties) and were all living in South Africa at the time of testing. The L2 learners had all been born in South Africa (except for one L2 learner who had been born in Namibia) and had all spoken only Afrikaans at home while growing up. Their ages at the onset of acquisition ranged from 13 to 28 years and their length of exposure ranged from 2 to 9 years. Researchers who believe in a Critical Period for L2 acquisition disagree as to the exact cut-off point(s) for this period. For the purposes of this paper, the L2 learners were not divided into child versus adult L2 learners despite the fact that six of them had started acquiring the L2 before the age of 16, and 15 of them had started acquiring the L2 after the age of 18. However, when the participants were divided into these two groups for statistical analysis, no significant differences were found between the two groups (Conradie 2005: section 5.3).

All of the L2 learners were either second-year or third-year students in the Department of Modern Foreign Languages at Stellenbosch University at the time of testing. In the first-year French course taught here, the focus is on the grammar of French and in subsequent years, the focus is on a study of French literature with very little discussion of French grammar. In these 
classes, only French is used by the lecturer and the students, as far as this is possible. French is not one of South Africa's official languages and it is not spoken as a native language by any larger communities within or around Stellenbosch. One would thus have to make a conscious effort to receive exposure to this language outside of an L2 French classroom.

The larger study referred to above (Conradie 2005) involved testing the learners' knowledge of verb placement in addition to their knowledge of TECs and OSCs, but in this paper I will only discuss those parts of the tasks and the results that are related to TECs and OSCs.

\subsection{Tasks}

Both groups (the L2 learners and the controls) completed a sentence manipulation task and a grammaticality judgement task. The instructions on both tasks were given in the participants' L1s - French for the controls and Afrikaans for the L2 learners.

In the sentence manipulation task, participants were handed sets of French word cards and asked to rearrange them in order to form as many as possible sentences that they found acceptable in French. Each set of word cards was designed specifically to elicit a particular construction type. Unfortunately, this kind of task cannot be used to elicit TECs: if a participant's IL grammar does not allow TECs and he is handed a set of word cards that contains a transitive verb and an expletive, then he would have to respond by saying that he cannot form a single sentence with the set of word cards. Furthermore, such a participant might feel forced to form at least one sentence with the cards and so might end up forming a sentence that he does not find completely acceptable. For this reason, only the OSC-part of the sentence manipulation task is relevant here. There were 15 sets of word cards in total and six of them were specifically designed to elicit OSCs: three sets with a sentence-medial adverb (see (5) below) and three with negation (see (6) below). (In the examples below, words that occur on a single card are enclosed in square brackets.) The participants receive the word cards in random order and, given the word cards in (5) might then decide to build a grammatical non-OSC such as that in (5a) (in which the direct object l'herbe 'the grass' follows the adverb souvent 'often'), and/or an ungrammatical OSC such as that in (5b) (in which the direct object l'herbe precedes the adverb souvent).

\section{OSC - adverb}

a. [Le jardinier $][$ a] [souvent $]$ [coupé $][$ l'herbe $]$. the gardener has often cut the.grass

"The gardener often cut the grass."

b. $\quad *[$ Le jardinier $][a][l$ 'herbe $]$ [souvent $]$ [coupé]. the gardener has the.grass often cut

(6) OSC - negation

a. $\quad[$ Gert $][$ ne $][$ peut $][$ pas $][$ conduire] [cette voiture $]$.

Gert NEG may not drive that car

"Gert is not allowed to drive that car."

b. $\quad *[$ Gert $][$ ne $][$ peut $][$ cette voiture $][$ pas $]$ [conduire $]$. Gert NEG may that car not drive

In the grammaticality judgement task, participants were presented with 50 sentence pairs and were asked to circle one of the options below each pair: only $(a)$ is possible, only $(b)$ is possible, both possible, both impossible or don't know. Example (7) shows what an actual test 
item on this task looks like, i.e. without English glosses and indications of (un)grammaticality.

(7) a. Beaucoup de personnes ont mangé du poisson.

b. Il y avait beaucoup de personnes mangé du poisson.

Only (a) is possible / Only (b) is possible / Both possible / Both impossible / Don't know

Of the 50 sentence pairs on the task only the five TEC-pairs and the 15 OSC-pairs are relevant here. The reason that there were so many OSC-pairs was to investigate whether it mattered to the participants what the relevant element was that the object was being shifted across (i.e. what the relevant left-edge marker was). There were five pairs with a sentence-medial adverb, five with negation and five with a floating quantifier. An example of a TEC-pair is given in (8) and an example of each type of OSC-pair is given in (9) to (11).

(8) TEC (only (a) is possible)

a. Beaucoup de personnes ont mangé du poisson. many of people have eaten of fish

"Many people ate fish at the wedding."

b. Il y avait beaucoup de personnes mangé du poisson.

EXPLETIVE have many of people eaten of fish

(9) OSC-adverb (only (b) is possible)

a. Rika a cette chanson souvent chanté. Rika has that song often sung

b. Rika a souvent chanté cette chanson.

Rika has often sung that song

"Rika often sung that song."

(10) OSC-negation (only (a) is possible)

a. Elle n'a pas connu son grand-père. she NEG.has not known her grandfather

"She did not know her grandfather."

b. Elle n'a son grand-père pas connu. she NEG.has her grandfather not known

(11) OSC-floating quantifier (only (a) is possible)

a. Rudie a invité tous ses meilleurs amis.

Rudie has invited all his best friends

"Rudie invited all of his best friends."

b. $\quad$ Rudie a ses meilleurs amis invité tous.

Rudie has his best friends invited all

Each TEC-pair contained an ungrammatical TEC and its grammatical non-TEC counterpart (which contained either a transitive verb or an expletive but not both). Each OSC-pair contained a grammatical non-OSC, in which the object followed the left-edge marker, and its ungrammatical OS counterpart, in which the object had been moved across a left-edge marker and thus preceded the left-edge marker. Item types and response types were distributed randomly in the task and the test pairs varied in terms of whether it was the (a)- or the (b)sentence that was grammatical. 


\subsection{Results}

If TECs and OSCs are ungrammatical in French, as claimed in Section 2, then we expect the French Controls (i) to build only non-OSCs in the sentence manipulation task and (ii) to accept only non-TECs and non-OSCs in the grammaticality judgement task, i.e. to respond with only $(a) /(b)$ is possible (rather than both possible) for sentence pairs such as those in (8) to (11) in the grammaticality judgement task.

The French Controls performed as expected. They did not build a single OSC in the sentence manipulation task, and in the grammaticality judgement task, they accepted only the non-TEC (rejecting the TEC) for $98 \%$ of the TEC-pairs, and they accepted only the non-OSC (rejecting the OSC) for $90 \%$ of the OSC-pairs.

If it is impossible for Afrikaans-speaking learners of French to acquire knowledge of the ungrammaticality of TECs and OSCs in French - as was argued at the end of Section 2 - then the L2 learners in this study should (i) build OSCs and non-OSCs in the sentence manipulation task, and (ii) accept both TECs and non-TECs, as well as both OSCs and nonOSCs in the grammaticality judgement task, i.e. respond with both possible for sentence pairs such as those in (8) to (11). This prediction was not borne out by the data; instead, the L2 learners' performance on both tasks indicates that they have indeed acquired knowledge of the ungrammaticality of TECs and OSCs in French. In the sentence manipulation task, the L2 learners performed like the French Controls, building no OSCs, and in the grammaticality judgement task, they accepted only the non-TEC (rejecting the TEC) for $74 \%$ of the TECpairs, and they accepted only the non-OSC (rejecting the OSC) for 79\% of the OSC-pairs.

Although these percentages are not as high as those of the French Controls, it should be kept in mind that chance level is $25 \%$ for this task (since there were four response options to choose from for each sentence pair). Furthermore, when a group of 20 native speakers of Afrikaans completed Afrikaans versions of the two tasks (cf. Conradie 2005: Section 5.1), they built 47 OSCs in total in the sentence manipulation task, and in the grammaticality judgement task they accepted both the TEC and the non-TEC for 93\% of the TEC-pairs, and they accepted both the OSC and the non-OSC for $81 \%$ of the OSC-pairs. This shows that native speakers of Afrikaans do build OSCs in an Afrikaans sentence manipulation task and that they do accept TECs and OSCs in an Afrikaans grammaticality judgement task. That the Afrikaans-speaking learners of French did not build any OSCs in the French sentence manipulation task and that they rejected TECs and OSCs for a high percentage of the relevant sentence pairs on the French grammaticality judgement task, shows that these learners have indeed acquired knowledge of the ungrammaticality of TECs and OSCs in French. However, the percentages for the L2 French grammaticality judgement task hide a lot of variation between participants. For this reason, it is necessary to examine the learners' individual performances on this task, presented in Table 1. 
Table 1. Advanced L1Afr/L2French: Grammaticality judgement task (Individual results presented as percentage of accurate judgements)

\begin{tabular}{|l|l|l|l|l|l|l|l|l|l|l|l|}
\hline Subj \# & FA1 & FA2 & FA3 & FA4 & FA5 & FA6 & FA7 & FA8 & FA9 & FA10 & FA11 \\
\hline $\begin{array}{l}\text { TECs } \\
\text { n=5 }\end{array}$ & 60 & 100 & 100 & 0 & 0 & 10 & 100 & 60 & 10 & 100 & 100 \\
\hline $\begin{array}{l}\text { OSCs } \\
\text { n=15 }\end{array}$ & 79 & 64 & 79 & 71 & 67 & 93 & 100 & 53 & 60 & 93 & 93 \\
\hline
\end{tabular}

\begin{tabular}{|l|l|l|l|l|l|l|l|l|l|l|l|}
\hline $\begin{array}{l}\text { Subj } \\
\#\end{array}$ & FA12 & FA13 & FA14 & FA15 & FA16 & FA17 & FA18 & FA19 & FA20 & FA21 & MEAN \\
\hline $\begin{array}{l}\text { TECs } \\
\mathbf{n = 5}\end{array}$ & 100 & 60 & 40 & 100 & 100 & 60 & 100 & 0 & 0 & 100 & $\mathbf{7 4}$ \\
\hline $\begin{array}{l}\text { OSCs } \\
\mathbf{n = 1 5}\end{array}$ & 93 & 80 & 73 & 67 & 47 & 93 & 86 & 93 & 73 & 93 & $\mathbf{7 9}$ \\
\hline
\end{tabular}

The cut-off point for deciding whether or not a learner has acquired knowledge of the ungrammaticality of TECs and/or OSCs is, inevitably, arbitrary. However, let us set the cutoff point at a very conservative $80 \%$, i.e. let us assume that only learners who rejected TECs for more than $80 \%$ of the TEC-pairs on this task have acquired knowledge of the ungrammaticality of TECs, and that only learners who rejected OSCs for more than $80 \%$ of the OSC-pairs on the task have acquired knowledge of the ungrammaticality of OSCs. With this conservative cut-off point, we can conclude that six of the 21 learners have acquired neither knowledge of the ungrammaticality of TECs nor knowledge of the ungrammaticality of OSCs in the target L2, but we can also conclude that 15 of the 21 L2 learners have acquired knowledge of the ungrammaticality of either TECs or OSCs or both.

\section{Discussion}

The performance of the $15 \mathrm{~L} 2$ learners referred to directly above is quite unexpected given the assumptions that (i) Afrikaans-speaking learners of French require negative evidence to realise that TECs and OSCs are ungrammatical in French, and (ii) such negative evidence is not available to them. One might question the second assumption, i.e. the unavailability of negative evidence: even though learners were not instructed on the ungrammaticality of TECs and OSCs and as such did not receive the relevant explicit negative evidence, they might have received implicit negative evidence whenever they produced TECs and OSCs in class and were then corrected by the teacher. However, Lyster and colleagues (see, for example, Lyster and Ranta 1997; Lyster 1998; Lyster and Mori 2006) have provided convincing evidence that implicit corrective feedback moves are seldom noticed by L2 learners and are highly ineffective as tools for developing a learner's knowledge of the L2.

I would like to propose that it is actually the first assumption mentioned above - i.e. that Afrikaans-speaking learners of French require negative evidence to acquire knowledge of the ungrammaticality of TECs and OSCs - that is incorrect. I will argue that if we abandon this assumption, we can account for the performance of the 15 L2 learners in this study in a straightforward way by assuming UG-involvement. ${ }^{1}$ 
If adult L2 learners, unlike L1 learners, employ their general problem-solving skills (rather than something like UG), to acquire an L2 (cf. Clahsen and Muysken 1986, 1989; BleyVroman 1990, 2009), then the individual construction types of the target L2 are (largely) unrelated for the learner and acquisition proceeds on a construction-by-construction basis. To acquire knowledge of hypothetical construction type $\mathrm{x}$, the learner will need to notice construction type $\mathrm{x}$ in the L2 data. In this scenario, the L2 learners' knowledge of the ungrammaticality of TECs and OSCs in French remains a mystery. As was mentioned, the learners were not instructed on the ungrammaticality of these construction types. Furthermore, they could not have acquired this knowledge by noticing the non-occurrence of TECs and OSCs in the L2 input: just because an L2 learner has not come across $x$ in the L2 input, this does not mean that $\mathrm{x}$ is not allowed in the target L2 - as we know, the utterances that we are exposed to in any language necessarily constitute a subset of all of the utterances that are possible in that language.

If, on the other hand, adult L2 learners, just like L1 learners, employ (something like) UG to acquire an L2, then the individual construction types of the target L2 are related to each other in that they cluster together under parameters and, therefore, acquisition does not proceed on a construction-by-construction basis. Instead, if properties $\mathrm{x}, \mathrm{y}$ and $\mathrm{z}$ are all related to a particular setting of hypothetical Parameter A, then the learner need only notice one of these properties to switch the parameter to its correct setting, and he gets knowledge of the other properties "for free". This means that the learner could acquire knowledge of construction type $\mathrm{x}$ either by noticing construction type $\mathrm{x}$ in the L 2 input or by noticing construction type $\mathrm{y}$ or $\mathrm{z}$ in the L2 input, i.e. by noticing one of the other properties that are linked to the same parameter setting. Importantly, though, the link between the hypothetical properties $\mathrm{x}, \mathrm{y}$ and $\mathrm{z}$ will not always be obvious to the investigating linguist, because parameters link superficially unrelated properties to each other.

I believe that this last point is the key to accounting for the results reported in the previous Section. I would like to propose that the L2 learners noticed something in the L2 input that to us, at this point in our understanding of human languages, seems unrelated to TECs and OSCs but that is actually linked to these properties at a deeper level. What this "something" is, is unclear at this stage but it is interesting to note that all languages that allow TECs and OSCs, have one thing in common: they all have both $\mathrm{V}$-to-I movement and $\mathrm{V}$-to- $\mathrm{C}$ movement. ${ }^{2,3}$ Afrikaans has both V-to-I movement (see (12a) and (12b)) and V-to-C movement (see (12c) and (12d)), whereas French has V-to-I movement (see (13a) and (13b)) but not V-to-C movement (see (13c) and (13d)).

\section{(12) Afrikaans}

a. Hulle verloor dikwels ' $n$ wedstryd. they lose often a game

"They often lose a game."

b. *Hulle dikwels verloor ' $n$ wedstryd. they often lose a game

c. Vandag eet die kinders brood. today eat the children bread "Today the children eat bread."

d. *Vandag die kinders eet brood. today the children eat bread

\section{$\sqrt{ }$ V-ADV}

*AVD-V

$\sqrt{ } \mathbf{V} 2$

*V3 


\section{(13) French}

\begin{tabular}{|c|c|c|}
\hline a. & $\begin{array}{l}\text { Ils perdent souvent un match. } \\
\text { they lose often a game } \\
\text { "They often lose a game." }\end{array}$ & $\sqrt{ } \mathbf{V}-\mathbf{A D V}$ \\
\hline b. & $\begin{array}{l}\text { *Ils souvent perdent un match. } \\
\text { they often lose a game }\end{array}$ & *ADV $-\mathrm{V}$ \\
\hline c & $\begin{array}{l}\text { Aujourd'hui les enfants mangent du pain. } \\
\text { today the children eat bread } \\
\text { "Today the children eat bread." }\end{array}$ & $\sqrt{ } \mathbf{V} 3$ \\
\hline & $\begin{array}{l}\text { *Aujourd'hui mangent les enfants du pain. } \\
\text { today eat the children bread }\end{array}$ & $* \mathbf{V} 2$ \\
\hline
\end{tabular}

Let us assume for a moment that this correlation that we find in natural languages, between the combination of V-to-I-movement and V-to-C movement, on the one hand, and the grammaticality of TECs and OSCs, on the other hand, is not coincidental, and that these two things are somehow linked to each other within UG. If this is the case, an Afrikaans-speaking learner of French could acquire knowledge of the ungrammaticality of TECs and OSCs in French simply by noticing V3-constructions such as that in (13c) in the input. The occurrence of V3-constructions in the input tells him that French does not have V-to-C movement, which in turn tells him that TECs and OSCs are not allowed in this language (given his unconscious UG-based knowledge that only languages that have V-to-I and V-to-C movement allow TECs and OSCs). In this scenario, it becomes unsurprising that some of the Afrikaans-speaking learners of French in the study reported above have managed to acquire knowledge of the ungrammaticality of TECs and OSCs, since there is in fact positive evidence to this effect in the L2 input, namely the occurrence of V3-constructions. ${ }^{4}$

Importantly, though, this account of the results of this study relies on the concept of superficially disparate properties clustering together in the L2 learner's mind, a concept that only makes sense within a UG-based account. In this way, the results of this study could be said to provide support for the claim that UG is involved in adult L2 acquisition.

It is my hope that this paper has contributed, even if only in a small way, to the discussion of the role of different types of input in (adult) L2 acquisition, specifically in the "unlearning" of properties that have been transferred from the L1.

\section{Acknowledgement}

A version of this paper was presented at the annual Linguistics Society of Southern Africa (LSSA) conference held at Stellenbosch University (South Africa) in January 2008. The data discussed in this paper were collected during my Ph.D. research (Conradie 2005), with the help of funding from the International Council for Canadian Studies and a number of research grants from McGill University, for which I am grateful. I would also like to express my gratitude to two anonymous reviewers for their valuable comments. All errors which remain are of course my own.

\section{Notes}

1. The debate regarding the involvement of UG in L2 acquisition is still a hot topic, as evidenced by a group of articles that appeared very recently in the journal Studies in Second Language Acquisition - cf. Belikova and White 2009; Bley-Vroman 2009; Montrul 2009; and Song and Schwartz 2009. 
2. The terms "V-to-I movement" and "V-to-C movement" are admittedly archaic and these phenomena have been referred to in different ways throughout the development of generative syntax. The terms are simply used here to refer to movement of the verb into the IP-complex (V-to-I) and movement of the verb into the CP-complex (V-to-C), respectively.

3. One reviewer claimed that this statement was not true, given that certain Bantu languages apparently allow TECs in the absence of V-to-C movement (Ndayiragiye 1999). If this is true, my proposal regarding the type of positive evidence that Afrikaans-speaking learners of French use to determine that TECs and OSCs are ungrammatical in the target L2, is not tenable. More research on the distribution of TECs and OSCs is thus needed, specifically taking Bantu languages into account.

4. One reviewer noted that these learners might have transferred from their L2 English the assumption that OSCs and TECs are ungrammatical in their L3 French. This is possible since all of the learners were also highly proficient in their L2 English. Although it is not clear how learners would decide when to transfer from their L1 and when to transfer from their L2 in L3 acquisition, transfer from the L2 to the L3 has indeed been reported in the literature (see, for example, Bohnacker 2004, 2006; Bardel and Falk 2007; and Leung 2007). This indicates the need for data from Afrikaansspeaking beginner learners of French in order to determine whether a crucial assumption in this paper, namely that such learners transfer from their L1 Afrikaans the assumption that TECs and OSCs are grammatical, is valid.

\section{References}

Bardel C. and Y. Falk. 2007. The role of the second language in third language acquisition: the case of Germanic syntax. Second Language Research 23: 459-484.

Belikova, A. and L. White. 2009. Evidence for the Fundamental Difference hypothesis or not? Studies in Second Language Acquisition 31(2): 199-223.

Bley-Vroman, R. 1990. The logical problem of foreign language learning. Linguistic Analysis 20: 3-49.

Bley-Vroman, R. 2009. The evolving context of the Fundamental Difference hypothesis. Studies in Second Language Acquisition 31(2): 175-198.

Bobaljik, J.D. and H. Thráinsson. 1998. Two heads aren't always better than one. Syntax 1(1): 37-71.

Bohnacker, U. 2004. Is V2 really that hard to acquire for second language learners? On current universalist L2 claims and their empirical underpinnings. Working papers in Scandinavian syntax 74: 43-79.

Bohnacker, U. 2006. When Swedes begin to learn German: from V2 to V2. Second Language Research 22: 443-486.

Carroll, S. 1999. Putting 'input' in its proper place. Second Language Research 15: 337-388.

Carroll, S., Y. Roberge and M. Swain. 1992. The role of feedback in adult second language acquisition: Error correction and morphological generalizations. Applied Psycholinguistics 13: 173-198.

Carroll, S. and M. Swain. 1993. Explicit and implicit negative feedback: An empirical study of the learning of linguistic generalizations. Studies in Second Language Acquisition 15: 357-386.

Clahsen, H. and P. Muysken. 1986. The availability of Universal Grammar to adult and child learners: A study of the acquisition of German word order. Second Language Research 2: 93-119. 
Clahsen, H. and P. Muysken. 1989. The UG paradox in L2 acquisition. Second Language Research 5: 1-29.

Conradie, S. 2005. Verb movement parameters in Afrikaans: Investigating the Full Transfer Full Access hypothesis. Unpublished Ph.D. dissertation, McGill University.

Conradie, S. 2007. The setting of the Split-IP parameter in Afrikaans: Evidence from transitive expletive constructions and object shift constructions. Stellenbosch Papers in Linguistics (SPIL) Plus 35: 53-86.

Ellis, R., S. Loewen and R. Erlam. 2006. Implicit and explicit corrective feedback and the acquisition of L2 grammar. Studies in Second Language Acquisition 28(2): 339-368.

Krashen, S. 1981. Second language acquisition and second language learning. Oxford: Pergamon Press.

Leung, Y.-K.I. 2007. Third language acquisition: why it is interesting to generative linguists. Second Language Research 23: 95-114.

Lightbown, P.M. and N. Spada. 1990. Form-focused and corrective feedback in communicative language teaching: Effects on second language learning. Studies in Second Language Acquisition 12: 429-448.

Long, M. 1991. Focus on form: A design feature in language teaching methodology. In K. de Bot, D. Coste, R. Ginsberg and C. Kramsch (eds). Foreign language research in crosscultural perspective. Amsterdam: Benjamins. pp. 39-52.

Lyster, R. 1998. Recasts, repetition, and ambiguity in L2 classroom discourse. Studies in Second Language Acquisition 20: 51-81.

Lyster, R. and L. Ranta. 1997. Corrective feedback and learner uptake. Negotiation of form in communicative classrooms. Studies in Second Language Acquisition 19: 37-66.

Lyster, R. and H. Mori. 2006. Interactional feedback and instructional counterbalance. Studies in Second Language Acquisition 28(2): 269-300.

MacLaughlin, D. 1992. Language acquisition and the subset principle. Paper presented at the $17^{\text {th }}$ Annual Boston University Conference on Language Development, Boston.

Marcus, G.F. 1993. Negative evidence in language acquisition. Cognition 46: 53-85.

Montrul, S. 2009. Reexamining the Fundamental Difference hypothesis. Studies in Second Language Acquisition 31(2): 225-257.

Ndayiragiye, J. 1999. Checking economy. Linguistic Inquiry 30: 399-444.

Schwartz, B.D. 1993. On explicit and negative data effecting and affecting competence and linguistic behaviour. Studies in Second Language Acquisition 15: 147-163.

Schwartz, B.D. and M. Gubala-Ryzak. 1992. Learnability and grammar reorganization in L2A: Against negative evidence causing the unlearning of verb movement. Second Language Research 8: 1-38.

Schwartz, B. D. and R. A. Sprouse. 1996. L2 cognitive states and the Full Transfer/Full Access model. Second Language Research 12: 40-72.

Song, H.S. and B.D. Schwartz. 2009. Testing the Fundamental Difference hypothesis. Studies in Second Language Acquisition 31(2): 323-361.

Thráinsson, H. 1996. On the (non-)universality of functional categories. In W. Abraham, S.D. Epstein, H. Thráinsson and C.J.-W. Zwart (eds). Minimal Ideas. Amsterdam: Benjamins. pp. 253-281.

Trahey, M. and L. White. 1993. Positive evidence and preemption in the second language classroom. Studies in Second Language Acquisition 15: 181-204.

Travis, L. 1991. Parameters of phrase structure and verb-second phenomena. In R. Freidin (ed.) Principles and parameters in comparative grammar. Cambridge, Mass.: MIT Press. pp. 339-364. 
Unsworth, S. 2008. Age and input in the acquisition of grammatical gender in Dutch. Second Language Research 24: 365-395.

White, L. 1987. Against comprehensible input: The input hypothesis and the development of L2 competence. Applied Linguistics 8: 95-110.

White, L. 1989. Universal Grammar and second language acquisition. Amsterdam/Philadelphia: John Benjamins Publishing Company.

White, L. 1991. Adverb placement in second language acquisition: some effects of positive and negative evidence in the classroom. Second Language Research 7: 133-161.

White, L. 1992. On triggering data in L2 acquisition: a reply to Schwartz and Gubala-Ryzak. Second Language Research 8: 120-137.

White, L. 2003. Second language acquisition and Universal Grammar: from initial to steady state. Cambridge: Cambridge University Press.

White, L., N. Spada, P.M. Lightbown and L. Ranta. 1991. Input enhancement and L2 question formation. Applied Linguistics 12: 416-432. 